\title{
Article \\ The Intestinal Biofilm of Pseudomonas aeruginosa and Staphylococcus aureus Is Inhibited by Antimicrobial Peptides HBD-2 and HBD-3
}

\author{
Alessandra Fusco ${ }^{1, * \mathbb{D}}$, Vittoria Savio ${ }^{1}$, Debora Stelitano ${ }^{1}$, Adone Baroni ${ }^{2}$ and Giovanna Donnarumma ${ }^{1, *(\mathbb{D})}$ \\ 1 Department of Experimental Medicine, University of Campania Luigi Vanvitelli, 80138 Naples, Italy; \\ vittoriasavio@libero.it (V.S.); debora.stelitano@unicampania.it (D.S.) \\ 2 Unit of Dermatology, Department of Mental Health and Physics and Preventive Medicine, University of \\ Campania “Luigi Vanvitelli", 80100 Naples, Italy; adone.baroni@unicampania.it \\ * Correspondence: alessandra.fusco@unicampania.it (A.F.); giovanna.donnarumma@unicampania.it (G.D.)
}

Citation: Fusco, A.; Savio, V.; Stelitano, D.; Baroni, A.; Donnarumma, G. The Intestinal Biofilm of Pseudomonas aeruginosa and Staphylococcus aureus Is Inhibited by Antimicrobial Peptides HBD-2 and HBD-3. Appl. Sci. 2021, 11, 6595. https://doi.org/10.3390/app 11146595

Academic Editor: Lidia Feliu

Received: 15 June 2021

Accepted: 14 July 2021

Published: 18 July 2021

Publisher's Note: MDPI stays neutral with regard to jurisdictional claims in published maps and institutional affiliations.

Copyright: (c) 2021 by the authors. Licensee MDPI, Basel, Switzerland. This article is an open access article distributed under the terms and conditions of the Creative Commons Attribution (CC BY) license (https:// creativecommons.org/licenses/by/ $4.0 /)$.

\begin{abstract}
Background: The intestinal microbiota is a very active microbial community interacting with the host in maintaining homeostasis; it acts in cooperation with intestinal epithelial cells, which protect the host from the external environment by producing a diverse arsenal of antimicrobial peptides (AMPs), including $\beta$-defensins-2 and 3 (HBD-2 and HBD-3), considered among the most studied in this category. However, there are some circumstances in which an alteration of this eubiotic state occurs, with the triggering of dysbiosis. In this condition, the microbiota loses its protective power, leading to the onset of opportunistic infections. In this scenario, the emergence of multi-drug resistant biofilms from Pseudomonas aeruginosa and Staphylococcus aureus is very frequent. Methods: We created a Caco-2 intestinal epithelial cell line stably transfected with the genes, encoding HBD-2 and HBD-3, in order to evaluate their ability to inhibit the intestinal biofilm formation of $P$. aeruginosa and S. aureus. Results: Both HBD-2 and HBD-3 showed anti-biofilm activity against $P$. aeruginosa and S. aureus. Conclusions: The exploitation of endogenous antimicrobial peptides as a new anti-biofilm therapy, in isolation or in combination with conventional antibiotics, can be an interesting prospect in the treatment of chronic and multi-drug resistant infections.
\end{abstract}

Keywords: biofilm; intestinal microbiota; dysbiosis; antimicrobial peptides; Pseudomonas aeruginosa; Staphylococcus aureus

\section{Introduction}

The intestinal microbiota is a very active microbial community comprised of 100 trillions of microbes, including bacteria, fungi, viruses and protozoa. Most microbial colonisers are innocuous, beneficial, and able to mutually interact with the host to play a role in homeostasis maintenance, and protect the host from the environment [1]. Such microbiota are also involved in the storage of energy and are able, thanks to the production of various enzymes, to influence the metabolism of the host. This feature is believed to be an evolution of bacteria towards the condition of human symbionts [2].

In addition to microbiota, the cells of the intestinal epithelium represent the second barrier in the line of defense between the host and the environment. This occurs through the presence of tight junctions (TJs), which physically strengthen the barrier [3], and by the production of molecules, such as cytokines, chemokines and antimicrobial peptides (AMPs), capable of activating the mechanisms of the innate immune system [4-6]. AMPs are highly conserved peptides expressed constitutively, or induced by microorganisms through mechanisms involving the activation of Pattern Recognition Receptors (PRRs) in intestinal epithelial cells $[7,8]$. The two main classes of AMPs include cathelicidins and defensins of which $\beta$-defensin-2 and $\beta$-defensin-3 (HBD-2 and HBD-3) are of particular importance $[9,10]$. 
HBD-2 acts as an endogenous antibiotic in the defence against Gram-negative bacteria, while HBD-3 exhibits antimicrobial activity against Gram-positive and Gram-negative bacteria and fungi $[9,10]$.

In physiological conditions, there is a balance and cooperation between microbiota and the cells of the intestinal epithelium [11]; however, there are circumstances where an alteration of this eubiotic state occurs, triggering microdysbiosis. This severe imbalance of microbiota can occur due to various causes, such as antibiotic therapies, improper diet, lifestyle or some pathological conditions [12,13]. Moreover, it can lead to the onset of intestinal and extra-intestinal autoimmune and inflammatory diseases (type I diabetes, rheumatoid arthritis, ankylosing spondylosis, IBD, lung disease, atopy, non-alcoholic fatty liver disease, obesity, atherosclerosis and carcinogenesis among others) [14]. Furthermore, since in this condition, the microbiota loses its protective power and ability to represent an anti-infective barrier, the host can be more easily infected by pathogenic environmental microorganisms and opportunistic members of the microbiota that have acquired the ability to display their pathogenic potential, leading to the onset of opportunistic infections. Most often, the transition from a healthy to a diseased microbiota is marked by the growth of thick pathogenic polymicrobial biofilms $[15,16]$.

Pseudomonas aeruginosa and Staphylococcus aureus infections are frequently found. These two species are well-known opportunistic, potent, biofilm-producing, nosocomial and food-borne pathogens, which can cause intestinal infections as common colonisers of the human intestine in hospitalised, immune-compromised or antibiotic-treated patients [17-20].

P. aeruginosa is a ubiquitous Gram-negative opportunistic pathogen, for which the human intestine of immune-compromised patients [17,21-25] or individuals suffering from some pathologies such as irritable bowel syndrome or ulcerative colitis [26-28] represent a natural reservoir. The intestinal transport of $P$. aeruginosa can cause diarrheic syndromes in subjects exposed to prolonged antibiotic therapy [29], or intestinal diseases accompanied by sepsis, such as "Shanghai fever" [30]. Its colonisation can be accompanied by invasion of the bloodstream, resulting in bacteraemia. In such patients, intestinal colonisation by $P$. aeruginosa alone has been associated with a three-fold increase in mortality in critically ill patients [31]. Furthermore, the strong ability to form biofilms in many environments renders antibiotic therapies ineffective and leads to the onset of chronic conditions $[17,32]$.

S. aureus is a Gram-positive opportunistic and resilient human pathogen, a causative agent of severe acute and chronic infections, that colonises mucous surfaces and is often involved in polymicrobial co-infections [33]. It may interact with other species in a cooperative manner, such as with Candida albicans [34,35], Enterococcus faecalis [36], Haemophilus influenzae [37,38] and influenza virus, [39] or in competitive ways, such as with P. aeruginosa, Streptococcus pneumonia [37,38], Lactobacillus spp. [40-42] and Corynebacterium spp. [43,44]. Several studies have shown that $S$. aureus colonises the intestines of newborns and that its presence in these early stages of development may be related to allergic phenomena [45]. It is also one of the most common food-borne pathogens, responsible for over 240,000 gastrointestinal infections per year [46]. Its pathogenic potential has increased in recent years following the emergence of multi-drug resistant strains, such as the MRSA strain (Methicillin-resistant S. aureus), which represents an important public health problem as it is easily isolated in community settings [47]. Its ability to produce biofilms is due to the production of intercellular polysaccharide adhesion (PIA), one of the most important biofilm components, encoded by the icaADBC cluster gene [48].

Due to the increased resistance to antibiotics and conventional treatment of bacteria in biofilms, finding substances or new therapeutic approaches to inhibit biofilm formation or trigger mature biofilm disassembly attracts considerable interest. In addition, inhibition of bacterial virulence and/or biofilm formation by targeting non-microbicidal mechanisms, are examples of increasingly explored antipathogenic strategies. 
We recently [10] created a Caco-2 cell line stably transfected with the genes encoding the HBD-2 and HBD-3 antimicrobial peptides and evaluated their role during acute infections with Salmonella enterica subsp. enterica serovar typhimurium [10] and C. albicans [3].

The aim of this work is to test a new approach in the prevention of and therapy for biofilm-borne infections of $P$. aeruginosa and S. aureus, based on the increased production of antimicrobial peptides HBD-2 and HBD-3

\section{Materials and Methods}

\subsection{Cloning and Transfection}

The cloning and transfection procedure has been described earlier [10]. Briefly, total RNA was extracted using a High Pure RNA Isolation Kit (Roche Diagnostics, Monza, Italy) from primary cultures of human keratinocytes stimulated with the LPS of P. aeruginosa and TNF- $\alpha$ in order to obtain a high production of antimicrobial peptides. It was subsequently transcribed into complementary Cdna, and two pairs of degenerate primers [10] designed on their specific amino acid were used to amplify, by RT-PCR, genes coding HBD-2 and HBD-3 with FastStart High Fidelity (Roche Diagnostics). The amplified DNA fragments were subjected to restriction and sequencing analysis and cloned into the pEF/V5-HIS TOPO (Invitrogen, Carlsbad, NM, USA) vector using the T4 DNA ligase (Invitrogen, USA), in accordance with the manufacturer's protocol and then transformed into Escherichia coli TOP 10 (Invitrogen, USA). The cloning vectors, $\mathrm{pEF} / \mathrm{V} 5-\mathrm{HIS}$ TOPO-HBD-2 and $\mathrm{pEF} / \mathrm{V} 5-$ HIS TOPO-HBD-3, were extracted from the bacterial culture and amplified using a QIAprep Spin Midiprep Kit (QIAGEN, Germantown, MD, USA). Caco-2 cells were transfected using the IBAfect reagent (IBA), according to the manufacturer's manuals. After incubation, the success of the experiment was verified by the extraction of mRNA from treated cells and by the amplification of HBD-2 and HBD-3 genes by PCR [10]. Cell-free supernatants of the transfected cells were recovered by centrifugation and assayed for the HBD-2 and HBD3 concentration by an enzyme-linked immunosorbent assay (Phoenix Pharmaceuticals, Burlingame, CA, USA). For blasticidin selection, untransfected and transfected cells were cultured for 14 days in the presence of the following increasing concentrations of blasticidin S (Sigma-Aldrich, Darmstadt, Germany): 5, 10, 20, 50, 100 and $250 \mu \mathrm{g} / \mathrm{mL}$. Thereafter, MTT labelling reagent was added at a final concentration of $0.5 \mathrm{mg} / \mathrm{mL}$ [10].

\subsection{Cell Culture}

Caco-2 cells (Human Caucasian colon adenocarcinoma cells, ATCC ${ }^{\circledR}$ HTB-37 ${ }^{\mathrm{TM}}$ ) were routinely cultured in Dulbecco's modified Eagle medium (DMEM, Gibco, Waltham, MA, USA), supplemented with $1 \%$ Penstrep, $1 \%$ glutamine, and 10\% foetal calf serum (Gibco, USA) at $37{ }^{\circ} \mathrm{C}$ at $5 \% \mathrm{CO}_{2}$. After transfection, the cells were grown in the presence of $250 \mathrm{\mu g} / \mathrm{mL}$ blasticidin (InvivoGen, San Diego, CA, USA) in a sterile $25 \mathrm{~cm}^{2}$ flask at a concentration of $3 \times 10^{5}$ to confluence for 21 days to reach full differentiation and polarisation $[3,10]$. The culture medium was changed every two days.

\subsection{Bacterial Strains}

P. aeruginosa $\mathrm{ATCC}^{\circledR} 9027^{\mathrm{TM}}$ and S. aureus $\mathrm{ATCC}^{\circledR} 6538^{\mathrm{TM}}$ were cultured in Bacto Tryptic Soy Broth (TSB - Difco Laboratories, Detroit, MI, USA). These strains were grown at $37^{\circ} \mathrm{C}$ for $18 \mathrm{~h}$.

\subsection{Biofilm Formation Assay}

For the biofilm assay, overnight cultures of $P$. aeruginosa and S. aureus were diluted with TSB (Oxoid), as positive control in cell culture supernatants of Caco-2, Caco-2/HBD-2 and Caco-2/HBD-3 to obtain a concentration of $10^{7} \mathrm{CFUs} / \mathrm{mL}$; aliquots $(200 \mu \mathrm{L})$ of the diluted bacterial suspension were placed into 96-well, flat-bottomed, sterile polystyrene microplates (Costar, Corning, Inc., New York, NY, USA) and incubated overnight at $37^{\circ} \mathrm{C}$ in aerobic conditions. The biofilm formed was quantified by a modification of the crystal violet assay ( $\mathrm{O}^{\prime}$ Toole et al.) [49]. Briefly, after 2, 4, 6 and $24 \mathrm{~h}$, the attached bacteria were washed 
twice with $200 \mu \mathrm{L}$ of PBS and air-dried for $45 \mathrm{~min}$. The wells were then stained with $200 \mu \mathrm{L}$ of $0.5 \%$ aqueous crystal violet solution for $45 \mathrm{~min}$. The plates were rinsed with $200 \mu \mathrm{L}$ of sterile distilled water to remove excess dye and air-dried. The dye associated with attached biofilm was dissolved in a solution of $200 \mu \mathrm{L}$ of 100 ethanol, and the $\mathrm{OD}_{570} / 655$ absorbance was measured on a microplate reader (580 Biorad, Laboratories, Segrate, Milan, Italy).

\subsection{Biofilm Evaluation with Conventional Plate Counting}

For the determination of the number of viable sessile cells, the mature biofilm, obtained as described, was washed twice with sterile PBS to eliminate the planktonic cells and resuspended after vigorous cracking in TSB. Subsequently, serial dilutions were inoculated on TSA and incubated at $37{ }^{\circ} \mathrm{C}$ for $24 \mathrm{~h}$, followed by the counting of CFUs/mL. The experiments were carried out in triplicate [50].

\subsection{Biofilm Evaluation with Fluorescence Microscopy}

Biofilm formation was visualised using FilmTracer ${ }^{\mathrm{TM}}$ LIVE/DEAD ${ }^{\circledR}$ Biofilm Viability Kit (Invitrogen, USA) containing SYTO 9 dye $(3.34 \mathrm{mM})$ and propidium iodide $(20 \mathrm{mM})$. Briefly, the biofilm formed on 96-well, flat-bottomed, sterile polystyrene microplates as previously described, was stained for $30 \mathrm{~min}$ in the dark at room temperature, as manufacturer's instructions, then visualised with fluorescence microscopy. Fluorescent images were collected using a Nikon Ti2-U research inverted fluorescence microscope, (Nikon Instruments, Amsterdam, Netherlands) with beam path settings for FITC and TRITC-like labels. Stacks of about 20 images were collected using a $20 \times$ objective lens. The stain differentiates live bacteria from dead by staining living bacteria fluorescent green and the dead ones fluorescent red, while the background remains virtually non-fluorescent.

\subsection{Evaluation of Biofilm-Associated Gene Expression}

For the evaluation of the expression levels of genes associated with biofilm formation in $P$. aeruginosa and $S$. aureus, the mRNA of viable sessile cells, obtained following biofilm formation as previously described, was extracted using the Tri-Reagent as per manufacturer's instructions. Two hundred nanograms of mRNA were reverse-transcribed (Expand Reverse Transcriptase, Roche Dignostic, Italy) into complementary DNA (cDNA) using random hexamer primers (Random hexamers, Roche Diagnostic, Italy) at $42{ }^{\circ} \mathrm{C}$ for $45 \mathrm{~min}$, according to the manufacturer's instructions [3,10].

To confirm the success of the extraction, the samples were subjected to amplification of the $16 \mathrm{~S}$ sequence by PCR using primers 27F'-GGTAGAGTTTGATCCTGGCTCAG-3' and 518R 5'-ATTACCGCGGCTGCTGG-3' with the following program: initial denaturation at $94^{\circ} \mathrm{C}$ for $1^{\prime}$, followed by $94^{\circ} \mathrm{C}$ for $1^{\prime}, 58^{\circ} \mathrm{C}$ for $1^{\prime}$ and $72^{\circ} \mathrm{C}$ for $90^{\prime \prime}$ for 30 cycles and final elongation at $72{ }^{\circ} \mathrm{C}$ for $10^{\prime}$ (data not shown).

Real time PCR was carried out with the LC Fast Start DNA Master SYBR Green kit using $2 \mu \mathrm{L}$ of cDNA, corresponding to $10 \mathrm{ng}$ of total RNA in a $20 \mathrm{~mL}$ final volume, $3 \mathrm{mM}$ $\mathrm{MgCl}_{2}$ and $0.5 \mathrm{mM}$ sense and antisense primers (Table 1).

After amplification, melting curve analysis was performed by heating to $95^{\circ} \mathrm{C}$ for $15 \mathrm{~s}$ with a temperature transition rate of $20^{\circ} \mathrm{C} / \mathrm{s}$, cooling to $60{ }^{\circ} \mathrm{C}$ for $15 \mathrm{~s}$ with a temperature transition rate of $20^{\circ} \mathrm{C} / \mathrm{s}$ and then heating the sample at $0.1^{\circ} \mathrm{C} / \mathrm{s}$ to $95^{\circ} \mathrm{C}$. The results were then analysed using LightCycler software (Roche Diagnostics). The standard curve of each primer pair was established with serial dilutions of cDNA. All PCR reactions were run in triplicate. The specificity of the amplification products was verified by electrophoresis on a $2 \%$ agarose gel and visualisation by ethidium bromide staining $[3,10]$. 
Table 1. Primer sequences and amplification programs used in this work.

\begin{tabular}{|c|c|c|c|}
\hline Gene & Primers Sequence & Conditions & $\begin{array}{l}\text { Product } \\
\text { Size (bp) }\end{array}$ \\
\hline lasI & $\begin{array}{c}\text { 5'-CTACAGCCTGCAGAACGACA-3' } \\
\text { 5'-ATCTGGGTCTTGGCATTGAG-3' }\end{array}$ & $\begin{array}{c}2^{\prime} \text { at } 50^{\circ} \mathrm{C}, 10^{\prime} \text { at } 94^{\circ} \mathrm{C} \text {, and for } 40 \text { cycles } \\
5^{\prime \prime} \text { at } 94^{\circ} \mathrm{C}, 30^{\prime \prime} \text { at } 60^{\circ} \mathrm{C} \text { for } 40 \text { cycles }\end{array}$ & 168 \\
\hline $\operatorname{las} R$ & $\begin{array}{l}\text { 5'-ACGCTCAAGTGGAAAATTGG-3' } \\
\text { 5'-GTAGATGGACGGTTCCCAGA-3' }\end{array}$ & $\begin{array}{c}2^{\prime} \text { at } 50^{\circ} \mathrm{C}, 10^{\prime} \text { at } 94^{\circ} \mathrm{C}, 5^{\prime \prime} \text { and for } 40 \\
\text { cycles } 5^{\prime \prime} \text { at } 94^{\circ} \mathrm{C}, 30^{\prime \prime} \text { at } 60^{\circ} \mathrm{C}\end{array}$ & 247 \\
\hline pslA & $\begin{array}{l}\text { 5'-TCCCTACCTCAGCAGCAAGC-3' } \\
5^{\prime} \text {-TGTTGTAGCCGTAGCGTTTCTG-3' }\end{array}$ & $\begin{array}{c}5^{\prime} \text { at } 95^{\circ} \mathrm{C} \text {, and for } 40 \text { cycles } 5^{\prime \prime} \text { at } 95^{\circ} \mathrm{C} \text {, } \\
10^{\prime \prime} \text { at } 65^{\circ} \mathrm{C}, 10^{\prime \prime} \text { at } 72^{\circ} \mathrm{C}\end{array}$ & 656 \\
\hline$p p y R$ & $\begin{array}{l}\text { 5'-CGTGATCGCCGCCTATTTCC-3' } \\
\text { 5'-ACAGCAGACCTCCCAACCG-3' }\end{array}$ & $\begin{array}{c}5^{\prime} \text { at } 95^{\circ} \mathrm{C} \text {, and for } 40 \text { cycles } 5^{\prime \prime} \text { at } 95^{\circ} \mathrm{C} \text {, } \\
10^{\prime \prime} \text { at } 65^{\circ} \mathrm{C}, 5^{\prime \prime} \text { at } 72^{\circ} \mathrm{C}\end{array}$ & 160 \\
\hline$i c a A D$ & $\begin{array}{l}5^{\prime} \text {-GACAGTCGCTACGAAAAG-3' } \\
5^{\prime} \text {-AATAAGCTCTCCCTAACTA-3 } 3^{\prime}\end{array}$ & $\begin{array}{c}5^{\prime} \text { at } 95^{\circ} \mathrm{C} \text {, and for } 40 \text { cycles } 5^{\prime \prime} \text { at } 95^{\circ} \mathrm{C} \text {, } \\
10^{\prime \prime} \text { at } 55^{\circ} \mathrm{C}, 7^{\prime \prime} \text { at } 72^{\circ} \mathrm{C}\end{array}$ & 211 \\
\hline bap & $\begin{array}{l}5^{\prime} \text {-GGCGCAAGCAGCAGAATTA- }{ }^{\prime} \\
5^{\prime} \text {-CATAGTTCTTTGTGGTGTTGC-3' }\end{array}$ & $\begin{array}{c}5^{\prime} \text { at } 95^{\circ} \mathrm{C} \text {, and for } 40 \text { cycles } 5^{\prime \prime} \text { at } 95^{\circ} \mathrm{C} \text {, } \\
10^{\prime \prime} \text { at } 63^{\circ} \mathrm{C}, 20^{\prime \prime} \text { at } 72^{\circ} \mathrm{C}\end{array}$ & 901 \\
\hline
\end{tabular}

\subsection{Statistical Analysis}

Significant differences among groups were assessed through two-way ANOVA by using GraphPad Prism 6.0 (6.0 version, GraphPad Software, San Diego, CA, USA, 2012), and the comparison between the means was calculated by $t$-student test. The data are expressed as means \pm standard deviation (SD) of three independent experiments.

\section{Results}

\subsection{Biofilm Formation Assay}

The ability of $P$. aeruginosa and $S$. aureus to form biofilms was tested after re-suspension of the bacteria in conditioned media of Caco-2, Caco-2/HBD-2 and Caco-2/HBD-3 cells by staining with crystal violet. The results, as shown in Figure 1, indicate that biofilm formation of P. aeruginosa is significantly inhibited in the presence of HBD-2 and slightly in the presence of HBD-3, while in the case of S. aureus, the biofilm formation is strongly inhibited in the presence of both anti-microbial peptides.

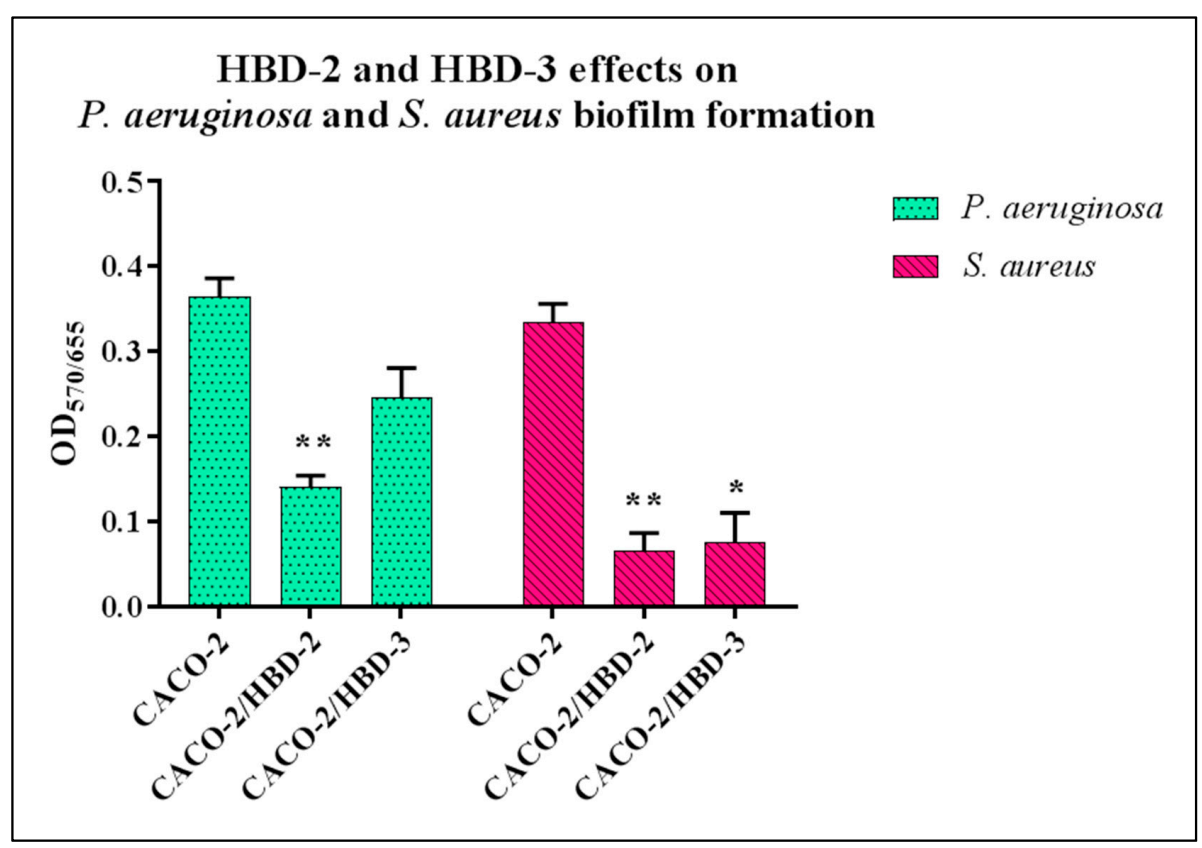

Figure 1. Evaluation of biofilm formation in P. aeruginosa and S. aureus re-suspended in conditioned media of Caco-2, Caco-2/HBD-2 and Caco-2/HBD-3 by crystal violet staining. Data are representative of three different experiments \pm SD. Significant differences are indicated by ${ }^{*} p<0.05,{ }^{* *} p<0.01$. 


\subsection{Viable Sessile Cells Counting}

Following the biofilm formation, the number of viable sessile cells was obtained by counting the $\mathrm{CFU} / \mathrm{mL}$ with serial dilutions plating on agar plates. As shown on Figure 2, for $P$. aeruginosa there is a significant decrease in viable cells, compared to the supernatants of Caco-2 $\left(\sim 8 \times 10^{8} \mathrm{CFU} / \mathrm{mL}\right)$, only in the presence of HBD-2 $\left(\sim 7.8 \times 10^{7} \mathrm{CFU} / \mathrm{mL}\right)$, while no reduction was found in the presence of HBD-3 $\left(\sim 7.5 \times 10^{8} \mathrm{CFU} / \mathrm{mL}\right)$. In this case, however, for $S$. aureus, the reduction is significant in the presence of both antimicrobial peptides $\left(\sim 7.8 \times 10^{8} \mathrm{CFU} / \mathrm{mL}\right.$ for Caco-2, $\sim 6 \times 10^{6} \mathrm{CFU} / \mathrm{mL}$ for both Caco-2/HBD-2 and -HBD-3).

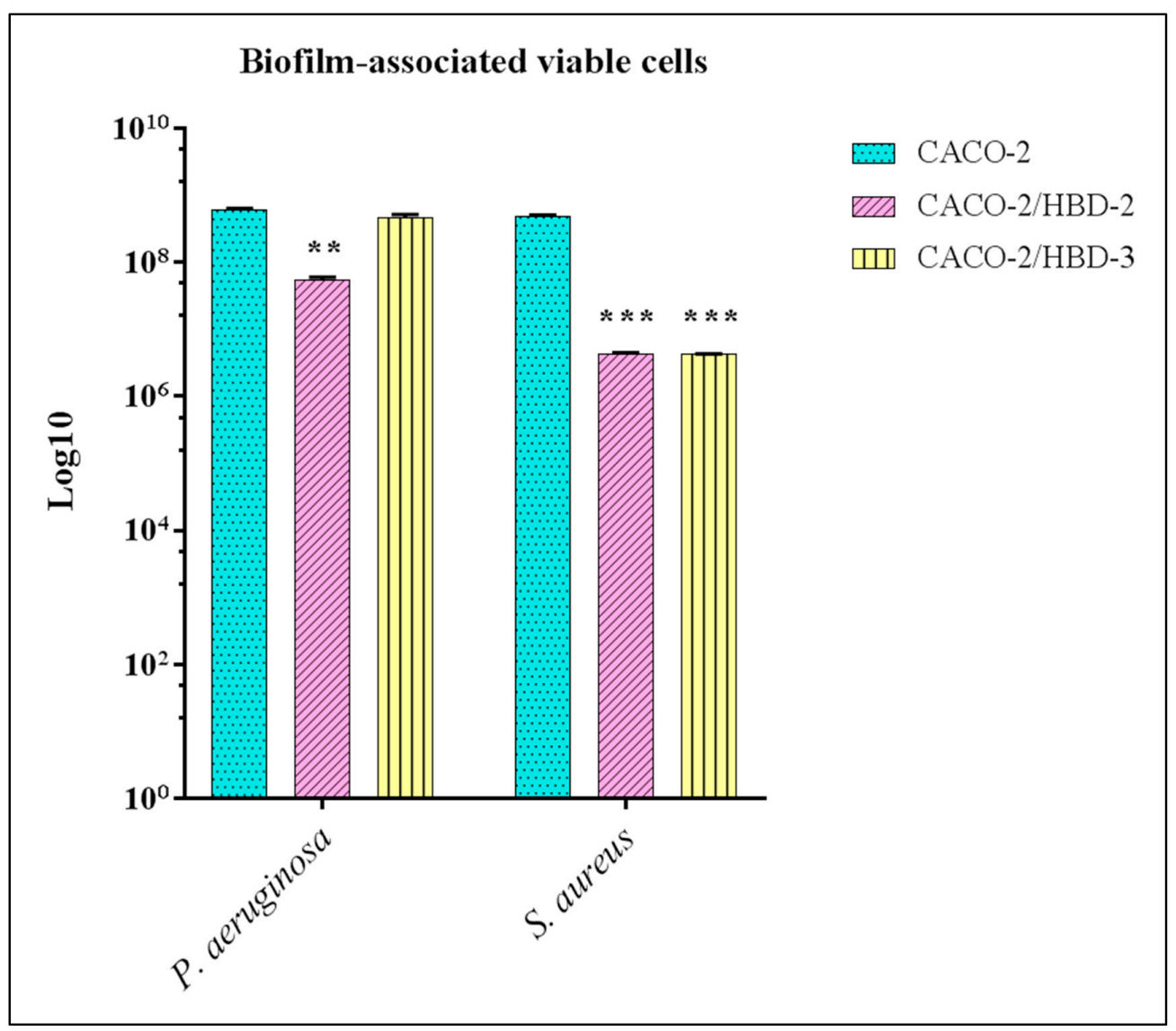

Figure 2. Viable cells counting of P. aeruginosa and S. aureus re-suspended in conditioned media of Caco-2, Caco-2/HBD-2 and Caco-2/HBD-3 after biofilm formation. Data are representative of three different experiments \pm SD. Significant differences are indicated by ${ }^{* *} p<0.01,{ }^{* * *} p<0.001$.

\subsection{Fluorescence Detection}

The biofilm analysis, performed with a fluorescence microscope following Live/Dead staining (Figure 3), shows an extended P. aeruginosa biofilm (Figure 3a) with a clear majority of live cells in the supernatants of the untransfected Caco-2 cells. The presence of HBD -2 induces a significant decrease of biofilm formation and, in the presence of HBD-3, inhibition of biofilm formation is present but less significant. S. aureus biofilm, present with the Caco-2 supernatants, almost completely disappears in the presence of HBD-2 and HBD-3, where only isolated colonies with a predominance of dead cells are shown (Figure $3 b$ ). 
P. aeruginosa

(a)
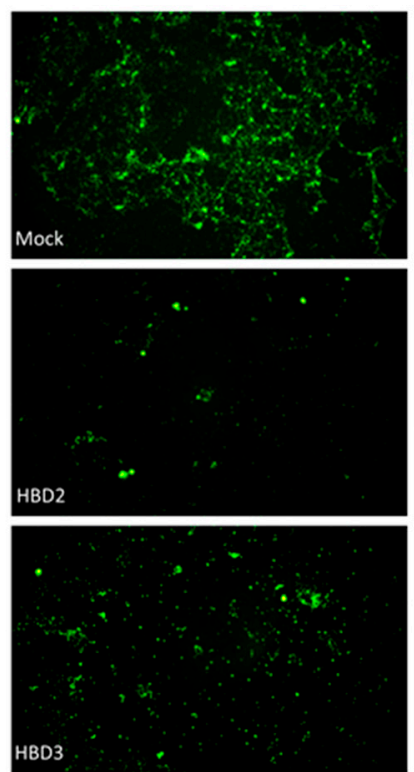

\section{S. aureus}

(b)
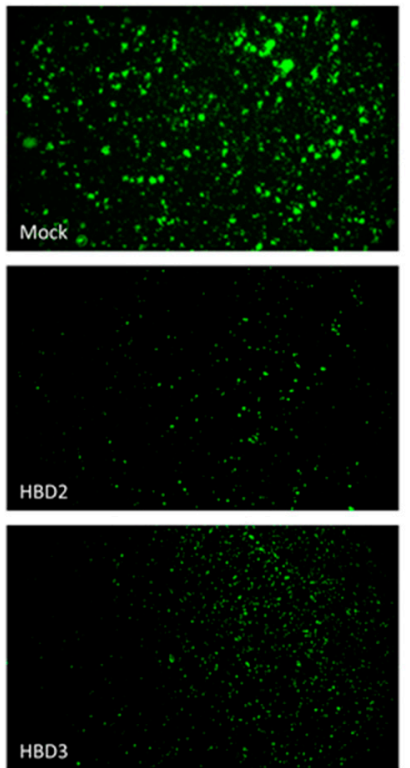

2
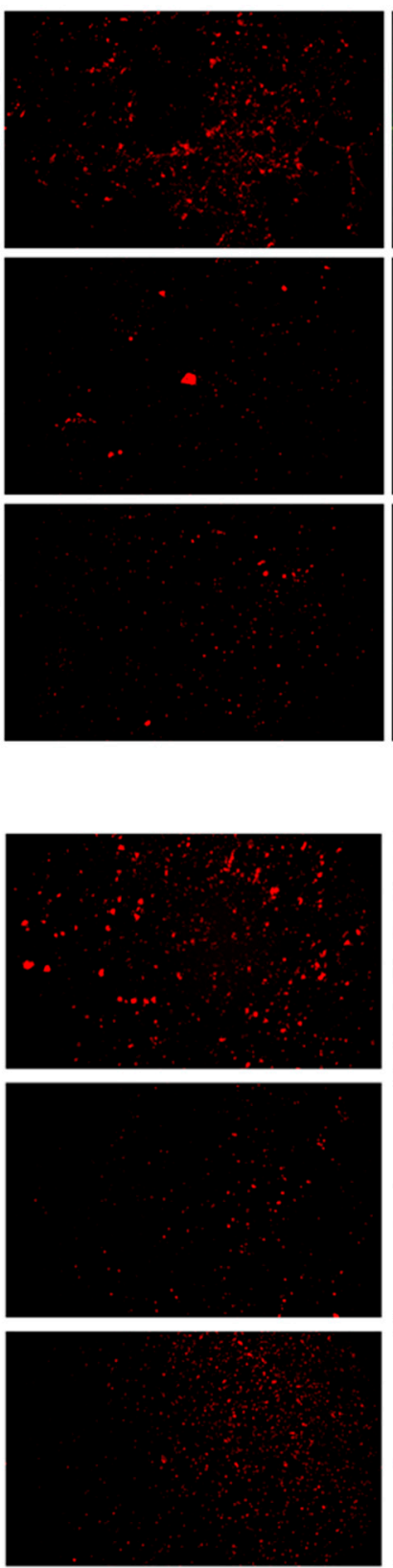
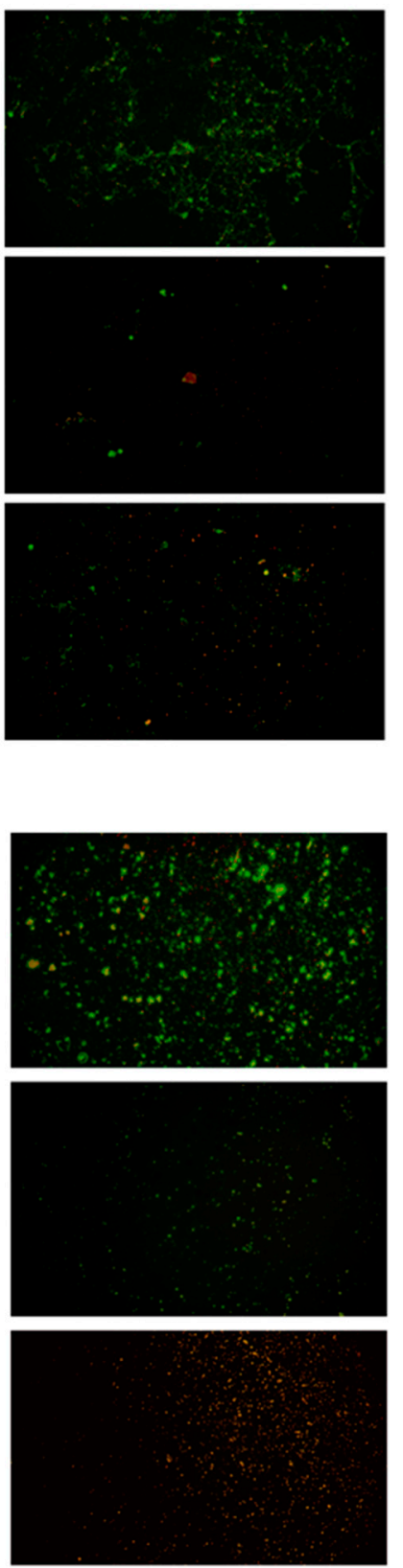

Figure 3. Live/Dead fluorescence $20 \times$ images of biofilms of (a) P. aeruginosa and (b) S. aureus resuspended in conditioned media of Caco-2, Caco-2/HBD-2 and Caco-2/HBD-3 cells. The panels show FITC-label (1), TRITC-label (2) and a merged image of both types of staining (3).

\subsection{Evaluation of Biofilm-Associated Gene Expression}

The evaluation of expression of $P$. aeruginosa biofilm-associated genes conducted by Real-Time PCR (Figure 4), shows a marked downregulation of all the genes analysed (lasI, lasR, pslA and ppyR) in the presence of HBD-2, compared to the supernatants of untransfected Caco-2. In the presence of HBD-3, no modulation is detected in most cases, except for the lasI gene which is strongly upregulated. In S. aureus, on the other hand, the analysed genes (icaAD and bap) are both strongly reduced in the presence of both antimicrobial peptides. 
(a)

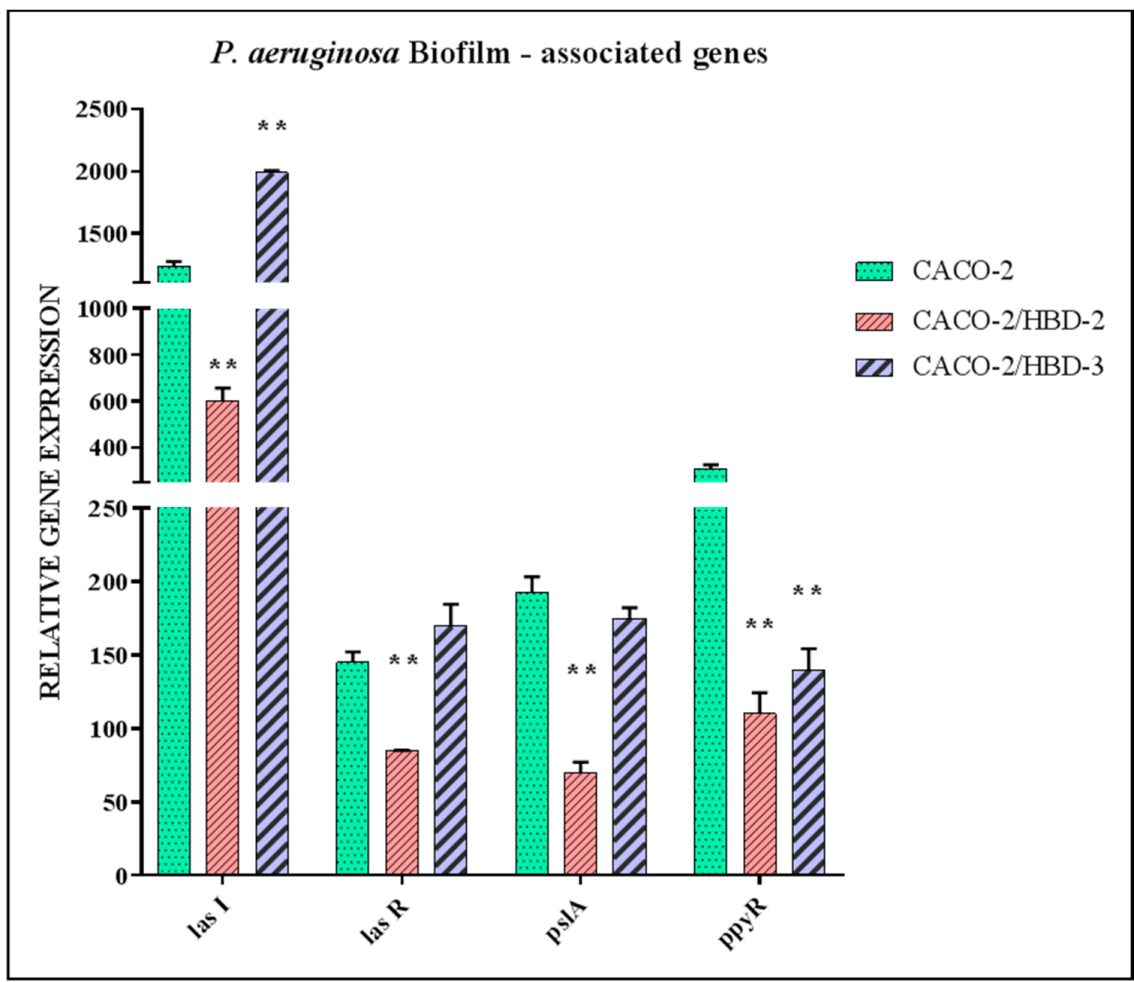

(b)

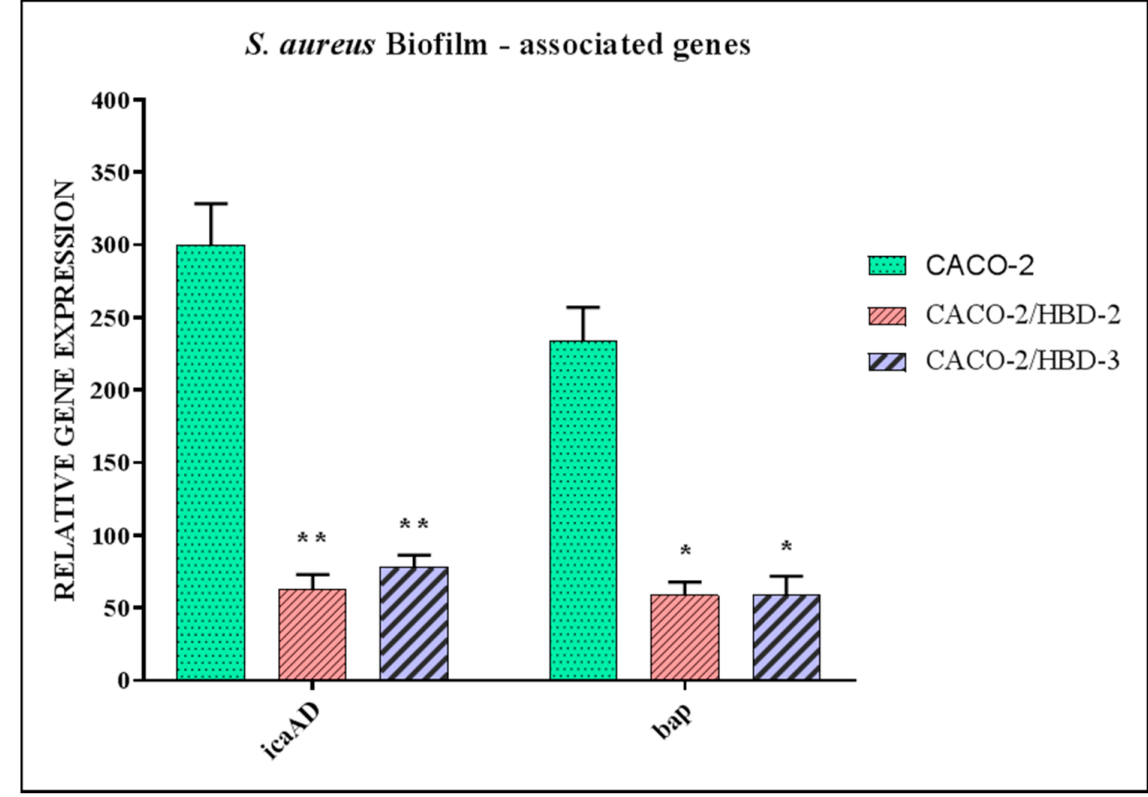

Figure 4. Real-Time PCR results show the effects of HBD-2 and HBD-3 on expression of biofilmassociated genes in P. aeruginosa (a) and S. aureus (b) re-suspended in conditioned media in Caco2/HBD-2 and Caco-2/HBD-3 cells, shown as relative gene expression. Data are representative of three different experiments \pm SD. Significant differences are indicated by ${ }^{*} p<0.05,{ }^{* *} p<0.01$.

\section{Discussion}

The ability of microorganisms to produce biofilms is considered an important virulence factor. During biofilm formation, microorganisms secrete natural polymers called highly hydrated extracellular polymeric substances (EPS), including polysaccharides, proteins and extracellular DNA (eDNA) [51] that embed bacteria and protect them from antimicrobial agents [52]. This enables the embedded bacteria to escape the defence mechanisms even of the host, and to resist much more than their planktonic counterparts to 
unfavourable conditions, such as a limited supply of nutrients, $\mathrm{pH}$ or inappropriate temperature. Increasing evidence suggests that the ability to form biofilms in many organisms involves quorum sensing (QS) regulation. QS is a cell density-dependent signalling system, in which bacteria produce and release a series of low molecular weight molecules called self-inductors which, once certain extracellular concentrations are reached, bind to their receptors present on bacterial cells, and regulate the expression of some genes fundamental for the formation of the biofilm [53].

In our experimental system, we created a line of human epithelial colorectal adenocarcinoma Caco-2 cells, stably transfected with the genes encoding the HBD-2 and HBD-3. Supernatants of transfected and untransfected cells were used to evaluate whether the presence of high concentration HBD-2 and HBD-3 may affect the intestinal biofilm formation of S. aureus and P. aeruginosa.

Biofilm production in S. aureus is linked to the release of an intercellular polysaccharide adhesin (PIA), involved in bacterial adhesiveness to target surfaces [54], which is the first critical event in the onset of infection [55]. PIA is encoded by the ica operon and its activity is linked to that of the biofilm associated protein (bap), a surface protein encoded by the homonymous gene [54].

The pronounced ability of $P$. aeruginosa to develop biofilm-associated disease has drawn considerable interest over the past decade to develop strategies to target their disassembly.

The QS system in P. aeruginosa controls over $10 \%$ of the entire genome, mainly regulating the expression of virulence factors, swarming motility, secondary metabolite production and biofilm formation. In particular, it consists of two subordinate systems, las and $r h l$. Specifically, the synthase lasI produces the self-inductor, N- (3-oxododecanoyl) -L-homoserine lactone (3O-C12-HSL), which can bind and activate its transcriptional regulator, lasR [56,57]. In addition, pslA genes play a significant role in the formation of carbohydrate-rich structure of biofilm matrix. The activation of the $p s l A$ operon is closely related to that of the $p p y R$ operon (putative transmembrane protein), a highly conserved gene responsible for the expression of the virulence genes of numerous clinical isolates, which enhance biofilm formation, and is endowed with elastase activity (as a virulence factor) [58]. In fact, it has been shown that psl operon was repressed following inactivation of the ppyR gene, and biofilm formation decreased [58].

For this purpose, cultures of $S$. aureus and $P$. aeruginosa, re-suspended in the supernatants of transfected and untransfected Caco-2, were tested for their ability to form biofilms according to different methods: first, the staining assay crystal violet was performed, followed by a biofilm evaluation with conventional plate counting. A microscopy analysis was also performed with the Live/Dead system using the fluorescence microscope. Finally, the expression of some of the genes mainly involved in the formation of the biofilm of the two bacterial species was evaluated by Real-Time PCR.

The results obtained showed that the $S$. aureus biofim is strongly inhibited by the presence of both peptides, both phenotypically and genotypically, while in the case of $P$. aeruginosa, the inhibition is significant in the presence of HBD-2. In the presence of HBD-3, only a slight decrease in biofilm formation is detected, which is not accompanied by a lowering of the expression levels of the biofilm-associated genes. The difference in this behaviour is probably due to the different compositions of cell wall and external structure of the two bacterial strains.

On the other hand, it was demonstrated that a complex matrix of biofilm can be affected in different ways by HBD-2 and HBD-3. For example, alginate has been shown to affect antimicrobial peptide conformation inducing alpha-helices contingent on the hydrophobicity, and HBD-2 and HBD-3 substantially differ in their hydrophobicity, with HBD-2 being more hydrophobic than HBD-3 [59]. 


\section{Conclusions}

Biofilm formation is often correlated with the onset of multidrug-resistant strains [58,59], which poses a threat to public health, as it results in increased patient morbidity with persistent infection, increased treatment costs, and hospitalisation rates [60].

The search for alternative therapeutic strategies is constantly evolving. For this purpose, it can be an interesting resource to increase in some way the production of enndogenous antimicrobial peptides through the intake of probiotics or functional and/or enriched foods (that stimulate their production). In this way, they could be tested alone or in combination with conventional antibiotic therapies.

Author Contributions: A.F. and G.D. designed the study. V.S. and D.S. were in charge of the laboratory procedures. A.F. and A.B. wrote the manuscript. A.F. and G.D. supervised and validated the original draft. All authors have read and agreed to the published version of the manuscript.

Funding: This research received no external funding.

Institutional Review Board Statement: Not applicable.

Informed Consent Statement: Not applicable.

Conflicts of Interest: The authors declare no conflict of interest.

\section{References}

1. Lin, L.; Zhang, J. Role of intestinal microbiota and metabolites on gut homeostasis and human diseases. BMC Immunol. 2017, 18, 1-25. [CrossRef] [PubMed]

2. Liang, D.; Leung, R.K.-K.; Guan, W.; Au, W.W. Involvement of gut microbiome in human health and disease: Brief overview, knowledge gaps and research opportunities. Gut Pathog. 2018, 10, 1-9. [CrossRef]

3. Fusco, A.; Savio, V.; Donniacuo, M.; Perfetto, B.; Donnarumma, G. Antimicrobial Peptides Human Beta-Defensin-2 and -3 Protect the Gut During Candida albicans Infections Enhancing the Intestinal Barrier Integrity: In Vitro Study. Front. Cell. Infect. Microbiol. 2021, 11, 666900. [CrossRef]

4. Mookherjee, N.; Anderson, M.A.; Haagsman, H.P.; Davidson, D.J. Antimicrobial host defence peptides: Functions and clinical potential. Nat. Rev. Drug Discov. 2020, 19, 311-332. [CrossRef]

5. Liang, W.; Diana, J. The Dual Role of Antimicrobial Peptides in Autoimmunity. Front. Immunol. 2020, 11, 2077. [CrossRef]

6. Browne, K.; Chakraborty, S.; Chen, R.; Willcox, M.D.; Black, D.S.; Walsh, W.R.; Kumar, N. A New Era of Antibiotics: The Clinical Potential of Antimicrobial Peptides. Int. J. Mol. Sci. 2020, 21, 7047. [CrossRef]

7. Muniz, L.R.; Knosp, C.; Yeretssian, G. Intestinal antimicrobial peptides during homeostasis, infection, and disease. Front. Immunol. 2012, 3, 310. [CrossRef] [PubMed]

8. Zhou, H.; Coveney, A.P.; Wu, M.; Huang, J.; Blankson, S.; Zhao, H.; O’Leary, D.P.; Bai, Z.; Li, Y.; Redmond, H.P.; et al. Activation of Both TLR and NOD Signaling Confers Host Innate Immunity-Mediated Protection Against Microbial Infection. Front. Immunol. 2019, 9, 3082. [CrossRef] [PubMed]

9. Donnarumma, G.; Paoletti, I.; Fusco, A.; Perfetto, B.; Buommino, E.; De Gregorio, V.; Baroni, A. $\beta$-Defensins: Work in Progress. Adv. Exp. Med. Biol. 2015, 901, 59-76. [CrossRef]

10. Fusco, A.; Savio, V.; Cammarota, M.; Alfano, A.; Schiraldi, C.; Donnarumma, G. Beta-Defensin-2 and Beta-Defensin-3 Reduce Intestinal Damage Caused by Salmonella typhimurium Modulating the Expression of Cytokines and Enhancing the Probiotic Activity of Enterococcus faecium. J. Immunol. Res. 2017, 2017, 1-9. [CrossRef]

11. Zheng, D.; Liwinski, T.; Elinav, E. Interaction between microbiota and immunity in health and disease. Cell Res. 2020, 30, 492-506. [CrossRef] [PubMed]

12. Hasan, N.; Yang, H. Factors affecting the composition of the gut microbiota, and its modulation. Peer J. 2019, 7, e7502. [CrossRef] [PubMed]

13. Sanders, M.E.; Merenstein, D.J.; Reid, G.; Gibson, G.R.; Rastall, R.A. Probiotics and prebiotics in intestinal health and disease: From biology to the clinic. Nat. Rev. Gastroenterol. Hepatol. 2019, 16, 605-616. [CrossRef]

14. De Gruttola, A.K.; Low, D.; Mizoguchi, A.; Mizoguchi, E. Current Understanding of Dysbiosis in Disease in Human and Animal Models. Inflamm. Bowel Dis. 2016, 22, 1137-1150. [CrossRef]

15. Tytgat, H.L.; Nobrega, F.L.; van der Oost, J.; de Vos, W.M. Bowel Biofilms: Tipping Points between a Healthy and Compromised Gut? Trends Microbiol. 2019, 27, 17-25. [CrossRef] [PubMed]

16. Motta, J.-P.; Wallace, J.L.; Buret, A.G.; Deraison, C.; Vergnolle, N. Gastrointestinal biofilms in health and disease. Nat. Rev. Gastroenterol. Hepatol. 2021, 18, 314-334. [CrossRef] [PubMed]

17. Von Klitzing, E.; Ekmekciu, I.; Bereswill, S.; Heimesaat, M.M. Intestinal and Systemic Immune Responses upon Multi-drug Resistant Pseudomonas aeruginosa Colonization of Mice Harboring a Human Gut Microbiota. Front. Microbiol. 2017, 8, 2590. [CrossRef] [PubMed] 
18. Senn, L.; Clerc, O.; Zanetti, G.; Basset, P.; Prod'Hom, G.; Gordon, N.C.; Sheppard, A.; Crook, D.W.; James, R.; Thorpe, H.A.; et al. The Stealthy Superbug: The Role of Asymptomatic Enteric Carriage in Maintaining a Long-Term Hospital Outbreak of ST228 Methicillin-Resistant Staphylococcus aureus. mBio 2016, 7, e02039-15. [CrossRef]

19. Nakao, A.; Ito, T.; Han, X.; Lu, Y.J.; Hisata, K.; Tsujiwaki, A.; Matsunaga, N.; Komatsu, M.; Hiramatsu, K.; Shimizu, T. Intestinal carriage of methicillin-resistant Staphylococcus aureus in nasal MRSA carriers hospitalized in the neonatal intensive care unit. Antimicrob. Resist. Infect. Control. 2014, 3, 14. [CrossRef] [PubMed]

20. Kates, A.E.; Thapaliya, D.; Smith, T.C.; Chorazy, M.L. Prevalence and molecular characterization of Staphylococcus aureus from human stool samples. Antimicrob. Resist. Infect. Control. 2018, 7, 1-9. [CrossRef] [PubMed]

21. Pettigrew, M.M.; Gent, J.F.; Kong, Y.; Halpin, A.L.; Pineles, L.; Harris, A.D.; Johnson, J.K. Gastrointestinal Microbiota Disruption and Risk of Colonization With Carbapenem-resistant Pseudomonas aeruginosa in Intensive Care Unit Patients. Clin. Infect. Dis. 2019, 69, 604-613. [CrossRef]

22. Koh, A.Y.; Mikkelsen, P.J.; Smith, R.S.; Coggshall, K.T.; Kamei, A.; Givskov, M.; Lory, S.; Pier, G.B. Utility of In Vivo Transcription Profiling for Identifying Pseudomonas aeruginosa Genes Needed for Gastrointestinal Colonization and Dissemination. PLoS ONE 2010, 5, e15131. [CrossRef]

23. Markou, P.; Apidianakis, Y. Pathogenesis of intestinal Pseudomonas aeruginosa infection in patients with cancer. Front. Cell. Infect. Microbiol. 2014, 3, 115. [CrossRef]

24. Hayashi, N.; Yokotani, A.; Yamamoto, M.; Kososhi, M.; Morita, M.; Fukunishi, C.; Nishizawa, N.; Gotoh, N. Extracellular Signals of a Human Epithelial Colorectal Adenocarcinoma (Caco-2) Cell Line Facilitate the Penetration of Pseudomonas aeruginosa PAO1 Strain through the Mucin Layer. Front. Cell. Infect. Microbiol. 2017, 7, 415. [CrossRef] [PubMed]

25. Von Klitzing, E.; Ekmekciu, I.; Bereswill, S.; Heimesaat, M.M. Acute ileitis facilitates infection with multidrug resistant Pseudomonas aeruginosa in human microbiota-associated mice. Gut Pathog. 2017, 9, 4. [CrossRef] [PubMed]

26. Kerckhoffs, A.P.M.; Ben-Amor, K.; Samsom, M.; Van Der Rest, M.E.; De Vogel, J.; Knol, J.; Akkermans, L.M.A. Molecular analysis of faecal and duodenal samples reveals significantly higher prevalence and numbers of Pseudomonas aeruginosa in irritable bowel syndrome. J. Med. Microbiol. 2011, 60, 236-245. [CrossRef] [PubMed]

27. Shukla, R.; Ghoshal, U.; Dhole, T.N.; Ghoshal, U.C. Fecal Microbiota in Patients with Irritable Bowel Syndrome Compared with Healthy Controls Using Real-Time Polymerase Chain Reaction: An Evidence of Dysbiosis. Dig. Dis. Sci. 2015, 60, $2953-2962$. [CrossRef] [PubMed]

28. Chong, P.P.; Chin, V.K.; Looi, C.Y.; Wong, W.F.; Madhavan, P.; Yong, V.C. The Microbiome and Irritable Bowel Syndrome-A Review on the Pathophysiology, Current Research and Future Therapy. Front. Microbiol. 2019, 10, 1136. [CrossRef]

29. Von Klitzing, E.; Ekmekciu, I.; Kühl, A.A.; Bereswill, S.; Heimesaat, M.M. Multidrug-resistant Pseudomonas aeruginosa aggravates inflammatory responses in murine chronic colitis. Sci. Rep. 2018, 8, 1-11. [CrossRef]

30. Hoff, R.T.; Patel, A.; Shapiro, A. Pseudomonas aeruginosa: An Uncommon Cause of Antibiotic-Associated Diarrhea in an Immunocompetent Ambulatory Adult. Case Rep. Gastrointest. Med. 2020, 2020, 1-3. [CrossRef]

31. Chuang, C.-H.; Wang, Y.-H.; Chang, H.-J.; Chen, H.-L.; Huang, Y.-C.; Lin, T.-Y.; Ozer, E.; Allen, J.; Hauser, A.R.; Chiu, C.-H. Shanghai fever: A distinct Pseudomonas aeruginosa enteric disease. Gut 2013, 63, 736-743. [CrossRef] [PubMed]

32. Zaborina, O.; E Kohler, J.; Wang, Y.; Bethel, C.; Shevchenko, O.; Wu, L.; Turner, J.R.; Alverdy, J.C. Identification of multi-drug resistant Pseudomonas aeruginosa clinical isolates that are highly disruptive to the intestinal epithelial barrier. Ann. Clin. Microbiol. Antimicrob. 2006, 5, 14. [CrossRef]

33. Sharma, D.; Misba, L.; Khan, A.U. Antibiotics versus biofilm: An emerging battleground in microbial communities. Antimicrob. Resist. Infect. Control. 2019, 8, 1-10. [CrossRef] [PubMed]

34. Nair, N.; Biswas, R.; Götz, F.; Biswas, L. Impact of Staphylococcus aureus on Pathogenesis in Polymicrobial Infections. Infect. Immun. 2014, 82, 2162-2169. [CrossRef] [PubMed]

35. Peters, B.M.; Noverr, M.C. Candida albicans-Staphylococcus aureus Polymicrobial Peritonitis Modulates Host Innate Immunity. Infect. Immun. 2013, 81, 2178-2189. [CrossRef]

36. Peters, B.M.; Jabra-Rizk, M.A.; Scheper, M.A.; Leid, J.G.; Costerton, J.W.; Shirtliff, M.E. Microbial interactions and differential protein expression in Staphylococcus aureus-Candida albicans dual-species biofilms. FEMS Immunol. Med. Microbiol. 2010, 59, 493-503. [CrossRef]

37. Weigel, L.M.; Donlan, R.M.; Shin, D.H.; Jensen, B.; Clark, N.C.; McDougal, L.K.; Zhu, W.; Musser, K.A.; Thompson, J.; Kohlerschmidt, D.; et al. High-Level Vancomycin-Resistant Staphylococcus aureus Isolates Associated with a Polymicrobial Biofilm. Antimicrob. Agents Chemother. 2007, 51, 231-238. [CrossRef]

38. Madhi, S.A.; Adrian, P.; Kuwanda, L.; Cutland, C.; Albrich, W.C.; Klugman, K.P. Long-Term Effect of Pneumococcal Conjugate Vaccine on Nasopharyngeal Colonization by Streptococcus pneumoniae-And Associated Interactions with Staphylococcus aureus and Haemophilus influenzae Colonization-In HIV-Infected and HIV-Uninfected Children. J. Infect. Dis. 2007, 196, 1662-1666. [CrossRef] [PubMed]

39. Margolis, E.; Yates, A.; Levin, B.R. The ecology of nasal colonization of Streptococcus pneumoniae, Haemophilus influenzae and Staphylococcus aureus: The role of competition and interactions with host's immune response. BMC Microbiol. 2010, 10, 59. [CrossRef] 
40. Niemann, S.; Ehrhardt, C.; Medina, E.; Warnking, K.; Tuchscherr, L.; Heitmann, V.; Ludwig, S.; Peters, G.; Löffler, B. Combined Action of Influenza Virus and Staphylococcus aureus Panton-Valentine Leukocidin Provokes Severe Lung Epithelium Damage. J. Infect. Dis. 2012, 206, 1138-1148. [CrossRef] [PubMed]

41. Li, J.; Wang, W.; Xu, S.X.; Magarvey, N.A.; McCormick, J.K. Lactobacillus reuteri-produced cyclic dipeptides quench agr-mediated expression of toxic shock syndrome toxin-1 in staphylococci. Proc. Natl. Acad. Sci. USA 2011, 108, 3360-3365. [CrossRef]

42. Eggers, S.; Barker, A.K.; Valentine, S.; Hess, T.; Duster, M.; Safdar, N. Effect of Lactobacillus rhamnosus HN001 on carriage of Staphylococcus aureus: Results of the impact of probiotics for reducing infections in veterans (IMPROVE) study. BMC Infect. Dis. 2018, 18, 129. [CrossRef] [PubMed]

43. Varma, P.; Nisha, N.; Dinesh, K.R.; Kumar, A.V.; Biswas, R. Anti-Infective Properties of Lactobacillus fermentum against Staphylococcus aureus and Pseudomonas aeruginosa. J. Mol. Microbiol. Biotechnol. 2011, 20, 137-143. [CrossRef]

44. Hardy, B.L.; Dickey, S.W.; Plaut, R.; Riggins, D.; Stibitz, S.; Otto, M.; Merrell, D.S. Corynebacterium pseudoiphtheriticum Exploits Staphylococcus aureus Virulence Components in a Novel Polymicrobial Defense Strategy. mBio 2019, 10, e02491-18. [CrossRef] [PubMed]

45. Menberu, M.A.; Liu, S.; Cooksley, C.; Hayes, A.J.; Psaltis, A.J.; Wormald, P.-J.; Vreugde, S. Corynebacterium accolens Has Antimicrobial Activity Against Staphylococcus aureus and Methicillin-Resistant S. aureus Pathogens Isolated from the Sinonasal Niche of Chronic Rhinosinusitis Patients. Pathogens 2021, 10, 207. [CrossRef]

46. Cukrowska, B.; Bierła, J.B.; Zakrzewska, M.; Klukowski, M.; Maciorkowska, E. The Relationship between the Infant Gut Microbiota and Allergy. The Role of Bifidobacterium breve and Prebiotic Oligosaccharides in the Activation of Anti-Allergic Mechanisms in Early Life. Nutr. 2020, 12, 946. [CrossRef] [PubMed]

47. Scallan, E.; Hoekstra, R.M.; Angulo, F.J.; Tauxe, R.V.; Widdowson, M.-A.; Roy, S.L.; Jones, J.L.; Griffin, P.M. Foodborne Illness Acquired in the United States-Major Pathogens. Emerg. Infect. Dis. 2011, 17, 7-15. [CrossRef]

48. Kadariya, J.; Smith, T.C.; Thapaliya, D. Staphylococcus aureus and Staphylococcal Food-Borne Disease: An Ongoing Challenge in Public Health. BioMed Res. Int. 2014, 2014, 1-9. [CrossRef]

49. Ghasemian, A.; Peerayeh, S.N.; Bakhshi, B.; Mirzaee, M. High Prevalence of Icaadbc Genes Responsible for Biofilm Formation in Clinical Isolates of Staphylococcus aureus From Hospitalized Children. Arch. Pediatr. Infect. Dis. 2015, 3, e20703. [CrossRef]

50. O'Toole, G.A.; Kolter, R. Initiation of biofilm formation in Pseudomonas fluorescensWCS365 proceeds via multiple, convergent signalling pathways: A genetic analysis. Mol. Microbiol. 1998, 28, 449-461. [CrossRef]

51. Fusco, A.; Coretti, L.; Savio, V.; Buommino, E.; Lembo, F.; Donnarumma, G. Biofilm Formation and Immunomodulatory Activity of Proteus mirabilis Clinically Isolated Strains. Int. J. Mol. Sci. 2017, 18, 414. [CrossRef] [PubMed]

52. Di Martino, P. Extracellular polymeric substances, a key element in understanding biofilm phenotype. AIMS Microbiol. 2018, 4, 274-288. [CrossRef]

53. Kouidhi, B.; Al Qurashi, Y.M.A.; Chaieb, K. Drug resistance of bacterial dental biofilm and the potential use of natural compounds as alternative for prevention and treatment. Microb. Pathog. 2015, 80, 39-49. [CrossRef] [PubMed]

54. Wu, L.; Luo, Y. Bacterial Quorum-Sensing Systems and Their Role in Intestinal Bacteria-Host Crosstalk. Front. Microbiol. 2021, 12, 611413. [CrossRef] [PubMed]

55. Earciola, C.R.; Campoccia, D.; Ravaioli, S.; Montanaro, L. Polysaccharide intercellular adhesin in biofilm: Structural and regulatory aspects. Front. Cell. Infect. Microbiol. 2015, 5, 7. [CrossRef]

56. Heilmann, C. Adhesion Mechanisms of Staphylococci. Adv. Exp. Med. Biol. 2011, 715, 105-123. [CrossRef]

57. Rasamiravaka, T.; Vandeputte, O.M.; Pottier, L.; Huet, J.; Rabemanantsoa, C.; Kiendrebeogo, M.; Andriantsimahavandy, A.; Rasamindrakotroka, A.; Stévigny, C.; Duez, P.; et al. Pseudomonas aeruginosa Biofilm Formation and Persistence, along with the Production of Quorum Sensing-Dependent Virulence Factors, Are Disrupted by a Triterpenoid Coumarate Ester Isolated from Dalbergia trichocarpa, a Tropical Legume. PLoS ONE 2015, 10, e0132791. [CrossRef] [PubMed]

58. Skariyachan, S.; Sridhar, V.S.; Packirisamy, S.; Kumargowda, S.T.; Challapilli, S.B. Recent perspectives on the molecular basis of biofilm formation by Pseudomonas aeruginosa and approaches for treatment and biofilm dispersal. Folia Microbiol. 2018, 63, 413-432. [CrossRef]

59. Attila, C.; Ueda, A.; Wood, T.K. PA2663 (PpyR) increases biofilm formation in Pseudomonas aeruginosa PAO1 through the psl operon and stimulates virulence and quorum-sensing phenotypes. Appl. Microbiol. Biotechnol. 2008, 78, 293-307. [CrossRef]

60. Parducho, K.R.; Beadell, B.; Ybarra, T.K.; Bush, M.; Escalera, E.; Trejos, A.T.; Chieng, A.; Mendez, M.; Anderson, C.; Park, H.; et al. The Antimicrobial Peptide Human Beta-Defensin 2 Inhibits Biofilm Production of Pseudomonas aeruginosa Without Compromising Metabolic Activity. Front. Immunol. 2020, 11, 805. [CrossRef] 